\title{
Optimalisasi Proses Bongkar Muat Minyak Produk di Dermaga Curah Cair PT. Pelindo III (Persero) Cabang Tanjung Emas Semarang
}

\author{
Fariz Mu'tasim ${ }^{a}$, Meinina ${ }^{b}$, Cahya Fajar Budi Hartanto ${ }^{c^{*}}$ \\ a,b,c Politeknik Bumi Akpelni \\ aEmail: simfaris76@gmail.com \\ bEmail: meinina.sugiarto@yahoo.com \\ c*Email: fajar@akpelni.ac.id
}

\begin{abstract}
ABSTRAK
PT. Pelabuhan Indonesia III (Persero) cabang Tanjung Emas Semarang merupakan BUMN penyedia jasa kepelabuhanan. Salah satu pelayanan yang disediakan adalah operasional kapal di pelabuhan seperti kegiatan bongkar muat. Salah satu kegiatan bongkar muat yang dilakukan adalah bongkar muat minyak produk di dermaga curah cair. Pada saat proses bongkar muat muatan minyak produk bisa saja terjadi beberapa hambatan atau gangguan yang menyebabkan keterlambatan pada saat proses bongkar muat sehingga menurunkan kinerja Badan Usaha Pelabuhan. Penelitian ini bertujuan untuk mengetahui faktor penghambat yang berasal dari tenaga kerja dan faktor lainnya serta mengetahui upaya untuk mengatasi hambatan tersebut. Metode pengumpulan data dilakukan dengan observasi atau pengamatan langsung di lokasi selama 3 bulan, wawancara, dan studi pustaka. Hasil penelitian menunjukkan bahwa faktor penghambat dari tenaga kerja mengakibatkan kurang optimalnya persiapan ruang muat dan pencucian tangki. Selain itu, faktor penghambat juga berasal dari kerusakan peralatan pendukung bongkar muat dan kondisi cuaca yang buruk. Penelitian ini memberikan rekomendasi agar setiap faktor penghambat diatasi dengan baik sesuai prosedur sehingga diharapkan dapat memberikan hasil yang positif yaitu kelancaran kegiatan bongkat muat minyak produk di dermaga curah cair PT. Pelabuhan Indonesia III (Persero) cabang Tanjung Emas Semarang.
\end{abstract}

Kata Kunci: bongkar muat, minyak produk, dermaga curah cair

\begin{abstract}
PT. Pelabuhan Indonesia III (Persero) branch of Tanjung Emas Semarang is a BUMN provider of port services. One of the services provided is the operation of ships at the port, such as loading and unloading activities. One of the loading and unloading activities is loading and unloading product oil at the liquid bulk dock. During the loading and unloading process of product oil, several obstacles or disruptions may occur which cause delays during the loading and unloading process, thus reducing the performance of the Port Business Entity. This study aims to determine the inhibiting factors originating from labor and other factors and to determine the efforts to overcome these obstacles. The method of data collection was carried out by observation or direct observation at the location for 3 months, interviews, and literature study. The results showed that the inhibiting factor of labor resulted in less optimal loading space and tank washing. In addition, the inhibiting factor also comes from damage to loading and unloading supporting equipment and bad weather conditions. This study provides recommendations for each inhibiting factor to be handled properly according to the procedure so that it is expected to provide positive results, namely the smooth loading of product oil at the liquid bulk dock of PT. Pelabuhan Indonesia III (Persero) Semarang branch of Tanjung Emas.
\end{abstract}

Keywords: loading and unloading, product oil, liquid bulk docks 


\section{PENDAHULUAN}

Pelabuhan adalah tempat yang terdiri atas daratan dan perairan dengan batas-batas tertentu sebagai tempat kegiatan pemerintah dan pengusahaan yang dipergunakan sebagai tempat kapal bersandar, naik turun penumpang, atau kegiatan bongkar muat barang. Pelabuhan dapat berupa terminal dan tempat berlabuh kapal yang dilengkapi dengan fasilitas keselamatan dan keamanan pelayaran dan kegiatan penunjang pelabuhan serta sebagai tempat perpindahan intra dan antarmoda transportasi. Pelabuhan juga berfungsi sebagai tempat kegiatan ekonomi yang diselenggarakan untuk menunjang sektor perindustrian, perdagangan, pertanian, pariwisata, pertambangan dan transportasi maupun angkutan laut melalui pemberian pelayanan jasa kepelabuhan.

Berdasarkan Undang-Undang Republik Indonesia No. 17 Tahun 2008 Tentang Pelayaran dan Keputusan Kementerian Perhubungan Republik Indonesia Nomor: KP.88 Tahun 2011 tentang Pemberian Izin Usaha kepada PT. Pelabuhan Indonesia III (selanjutnya disebut PT. Pelindo III) sebagai Badan Usaha Pelabuhan (BUP), mengakibatkan Pelabuhan Tanjung Emas Semarang bertransformasi dari Port Operator menjadi Terminal Operator dengan salah satu pelayanan yakni bongkar muat. Salah satu kegiatan bongkar muat yang dilakukan oleh BUP PT. Pelindo III cabang Tanjung Emas Semarang adalah bongkar muat minyak produk di dermaga curah cair.

Bongkar muat adalah suatu kegiatan membongkar ataupun memuat suatu muatan dari dermaga, tongkang, truk ke dalam palka atau geladak, dengan menggunakan derek atau katrol kapal maupun darat atau dengan alat bongkar lainnya, dimana barang yang dipindahkan dari dan ke atas kapal (Gianto \& Martopo, 2004). Bongkar muat juga berarti suatu pemindahan barang dari suatu tempat ke tempat lain dan bisa juga dikatakan pemindahan barang dari kapal ke dermaga atau sebaliknya (Badudu \& Zain, 2001). Pendapat lain menyatakan bongkar muat sebagai pemindahan muatan dari dan ke atas kapal untuk ditimbun ke dalam atau langsung diangkut ke tempat pemilik barang dengan melalui dermaga pelabuhan dengan mempergunakan alat pelengkap bongkar muat, baik yang berada di dermaga maupun yang berada di kapal itu sendiri (Sudjatmiko, 2015). Adapun dokumen yang terkait dalam bongkar muat antara lain Bill of Lading/ Konosemen, Tally Sheet, Daily Report, Statement of Facts/ Time Sheet, Cargo Manifest, dan Delivery Order (Suyono, 2007).

Minyak produk adalah sumber daya alam yang diolah dan memiliki banyak manfaat luas bagi kehidupan. Minyak produk berasal dari minyak mentah yang terbuat dari tumbuhtumbuhan yang mengental dalam kurun waktu jutaan tahun. Tidak heran jika minyak produk adalah bagian sumber daya alam yang tidak dapat diperbarui. Minyak produk merupakan bahan bermanfaat yang berasal dari minyak mentah setelah diproses di tempat pengolahan minyak (Moenir, 2006).

Proses bongkar muat minyak produk membutuhkan pengawasan dan pengendalian yang lebih baik supaya dapat berjalan dengan lancar serta mengutamakan kerja yang cepat dan efisien sesuai prosedur yang ditetapkan agar tidak merugikan PT. Pelindo III cabang Tanjung Emas Semarang. Prosedur bongkar muat minyak produk didasarkan pada prinsip-prinsip pemuatan yaitu melindungi kapal, melindungi muatan, melindungi keselamatan buruh dan anak buah kapal, menjaga kelestarian lingkungan, dan memuat atau membongkar secara tepat dan sistematis (Martopo, 2001). Adapun sistem yang berlaku di PT. Pelindo III cabang Tanjung Emas Semarang adalah sistem borongan atau mempekerjakan buruh dengan 3 shift kerja selama 24 jam yang biasa disebut dengan Tenaga Kerja Bongkar Muat atau TKBM (Adi \& 
Djaja, 2008). Tahapan yang dilakukan dalam proses bongkar muat tersebut adalah pre-arrival meeting, persiapan lapangan, dan persiapan peralatan meliputi cargo tank, cargo pump, serta pipeline and valve juga disiapkan (Samsul Huda et al., 2017).

Berdasarkan penelitian terdahulu, diketahui bahwa kurang maksimalnya persiapan tangki muatan dapat berpengaruh pada operasional kapal (Alabatjo, 2012). Akibat yang paling fatal dari ketidaksiapan tangki muatan adalah jika sampai terjadi kontaminasi muatan, meskipun itu bukan satu-satunya faktor penyebab (Antika et al., 2019). Demikian juga jika terjadi hambatan yang diakibatkan karena kurangnya keterampilan Anak Buah Kapal (ABK), maka dapat mengganggu penanganan bongkar muat minyak di kapal tanker (Cahyanto, 2019). Penelitian ini bertujuan untuk mengetahui hambatan dalam proses bongkar muat minyak produk di dermaga curah cair PT. Pelindo III cabang Tanjung Emas Semarang serta mengetahui upaya untuk mengatasi hambatan tersebut.

\section{METODE}

Penelitian ini merupakan penelitian deskriptif kualitatif. Pengumpulan data dilakukan dengan mengadakan observasi atau pengamatan langsung di PT. Pelindo III cabang Tanjung Emas Semarang selama 3 (tiga) bulan mulai 30 Agustus 2020 sampai dengan 1 Desember 2020. Selain itu dilakukan juga wawancara oleh peneliti kepada pimpinan dan pekerja di lokasi penelitian serta studi pustaka sebagai landasan teori dan pelengkap pembahasan hasil penelitian.

PT. Pelindo III cabang Tanjung Emas Semarang berdiri pada tanggal 1 Desember 1992. Perusahaan tersebut berlokasi di Jl. Coaster 10 Tanjung Emas Semarang, bersebelahan dengan Terminal Peti Kemas Semarang (TPKS). Perseroan mengelola 43 pelabuhan umum yang terdiri atas cabang utama, kelas I, II, III, dan kawasan di 7 (tujuh) wilayah provinsi Indonesia yakni Jawa Tengah, Jawa Timur, Kalimantan Tengah, Kalimantan Selatan, Bali, Nusa Tenggara Barat, dan Nusa Tenggara Timur. Perseroan juga berperan sebagai perusahaan induk (holding company) yang membawahi 11 anak usaha dan perusahaan afiliasi yang bergerak dalam beragam sektor yang terkait dengan pelabuhan seperti layanan kesehatan, logistik, peti kemas, pengelola terminal curah cair dan gas, sarana bantu pemanduan, operator terminal, penyedia tenaga kerja, jasa pemeliharaan, pengelolaan alur pelayaran, kawasan industri, bongkar muat, dan sebagainya.

\section{HASIL DAN PEMBAHASAN}

1. Hambatan Saat Bongkar Muat

Pada saat proses bongkar muat muatan minyak produk sering terjadi beberapa hambatan atau gangguan yang menyebabkan keterlambatan. Hambatan tersebut disebabkan oleh beberapa faktor, yaitu :

a. Faktor Manusia

Manusia merupakan pengaruh terbesar dalam proses kegiatan bongkar muat, salah satunya bongkar muat minyak olahan di dermaga curah cair PT. Pelindo III cabang Tanjung Emas Semarang. Beberapa kesalahan manusia (human error) yang mengakibatkan hambatan pada saat proses bongar muat dapat mengakibatkan kerugian. Kesalahan tersebut antara lain :

1) Kurang Optimalnya Persiapan Ruang Muat dan Pencucian Tangki (Tank Cleaning)

Persiapan ruang muat dan pencucian tangki merupakan proses awal yang harus dilakukan sebelum memuat muatan. Persiapan ini sangat penting dan harus benar-benar diperhatikan, terutama muatan yang berlainan jenis. Tangki harus dibersihkan dengan benar dan kering, tidak ada sisa air dan kotoran dari pembersih tangki. Kurang 
optimalnya persiapan ruang muat berarti kurangnya pemahaman dan pelaksanaan prosedur atau tata cara dalam mempersiapkan ruang muat dan pencucian tangki. Dalam pembersihan ruang muat ada pekerja yang tidak tahu bagaimana cara menggunakan peralatan untuk tank cleaning dan tahapan dalam melakukan pembersihan tangki. Hal ini membuat tank cleaning terhambat dan hasilnya tidak maksimal sehingga menyebabkan proses pemuatan tertunda. Faktor lain yang penting adalah faktor internal yaitu kerjasama seluruh $\mathrm{ABK}$ yang saling menunjang sesuai perannya masing-masing.

2) Kurangnya Keterampilan Tenaga Kerja Bongkar Muat (TKBM)

Dalam bekerja di pelabuhan maupun di atas kapal, seorang TKBM atau ABK dituntut untuk mengetahui dan melaksanakan tugas yang telah diberikan oleh Mandor lapangan maupun Nahkoda. Dengan adanya petugas bongkar muat yang tidak mengetahui langkah-langkah atau prosedur ketika melaksanakan kegiatan bongkar muat dapat menghambat kegiatan bongkar muat, bahkan bisa jadi mengakibatkan keadaan darurat yang akan timbul maupun pencemaran lingkungan seperti tumpahnya muatan ke laut yang dapat menimbulkan polusi di sekitar perairan pelabuhan (Widodo \& Wahyuni, 2020).

Setelah ditelusuri ada 2 (dua) penyebab sehingga TKBM tidak memiliki keterampilan yang cukup yaitu pertama, kurangnya penerapan prosedur kerja yang telah dibuat. Hal tersebut tampak pada banyaknya yang tidak memakai sepatu safety, kaos tangan safety, dan masih ada yang merokok pada saat kegiatan berjalan. Penyebab kedua adalah kurangnya pengawasan dari manager maupun Nahkoda. Sebagai pemimpin tertinggi di pelabuhan dan di kapal, keduanya harus melakukan pengontrolan dengan cara menerapkan International Safety Management (ISM) Code untuk memastikan kegiatan berjalan sesuai prosedur. Kurangnya keterampilan dalam proses bongkar muat juga dapat mengakibatkan kerusakan pada peralatan bongkar muat (Akhbar \& Darmana, 2019).

b. Faktor Alat Bongkar Muat

Alat merupakan sarana dan prasarana yang sangat penting dan berguna untuk membantu proses bongkar muat sehingga dapat memperlancar kegiatan. Bahkan ada penelitian yang menunjukkan bahwa peralatan menjadi faktor utama terjadinya idle time dimana kapal tidak bisa melakukan operasi bongkar muat (Safrianda et al., 2016). Oleh karena itu, sebelum digunakan, alat harus disiapkan terlebih dahulu. Akan tetapi di sini masih banyak terjadi kendala akibat dari kerusakan pada alat. Salah satunya adalah kerusakan pada pipa bongkar muat yang dapat mengakibatkan terhentinya proses bongkar muat. Biasanya pipa ini terbuat dari baja, karena kurangnya pengecekan terhadap alat-alat yang digunakan untuk bongkar muat, akibatnya pada saat akan menggunakan pipa ataupun peralatan lainya untuk kegiatan bongkar muat, alat tersebut rusak atau sudah tidak layak untuk digunakan. Kerusakan alat ini dapat mengakibatkan terkendalanya kegiatan bongkar muat dan juga bisa menjadikan pencemaran di sekitar dermaga. Terkadang ada juga pipa yang rusak atau bocor yang sudah tidak layak digunakan masih tetap dipakai saat kegiatan bongkar muat dengan cara menambal lubang tersebut menggunakan alat seadanya 
seperti karet bekas yang ditutupkan ke lubang pipa yang bocor tersebut.

Ada juga kerusakan pipa bongkar muat dikarenakan korosi. Faktor yang berpengaruh terhadap korosi dapat berasal dari bahan itu sendiri dan dari lingkungan. Faktor dari bahan itu sendiri meliputi kemurniaan bahan, teknik pencampuran, struktur bahan, bentuk kristal, unsur-unsur yang ada di dalam bahan dan sebagainya. Faktor dari lingkungan meliputi tingkat pencemaran udara, suhu, kelembaban, keberadaan zat-zat kimia yang bersifat korosif dan sebagainya. Secara kimia korosi ini terjadi karena terjadinya kontak antara lingkungan dengan bahan dalam pelaksanaan di kapal, pengaruh terbesarnya adalah sering terjadi karena air laut. Kondisi lingkungan yang tropis dengan tingkat humiditas yang tinggi dapat menjadikan pipa bongkar muat yang terbuat dari baja ini akan lebih mudah terkorosi, sehingga dibutuhkan perawatan khusus untuk menjaga pipa-pipa dan alat-alat yang lain agar tetap baik dan layak untuk digunakan sampai batas yang telah ditentukan.

c. Faktor Cuaca

Cuaca merupakan suatu kondisi alam yang tidak dapat diprediksi keadaannya, sehingga mengakibatkan terhambatnya proses bongkar muat minyak produk, khususnya pada saat proses pencucian tangki. Apabila kita memuat muatan yang berbeda jenis maka kita harus melaksanakan tank cleaning sebelum memuat muatan selanjutnya. Dalam proses ini dibutuhkan kerja keras dan cuaca sangat berpengaruh. Apabila terjadi cuaca buruk atau hujan maka pencucian tangki tidak dapat dilaksanakan karena dalam tank cleaning dibutuhkan pengeringan dengan bantuan sinar matahari. Maka dari itu, harus menunggu hingga cuaca mendukung untuk melaksanakan pembersihan tangki.

2. Akibat yang Ditimbulkan proses bongkar muat dapat menimbulkan efek yang buruk atau negatif, antara lain :

a. Menimbulkan kerugian waktu karena waktu terbuang banyak ketika hambatan itu terjadi.

b. Terkontaminasinya muatan yang dapat menimbulkan kerusakan terhadap muatan karena tercampur dengan muatan sebelumnya yang berbeda jenis karena kurangnya pembersihan tangki.

c. Kerugian terhadap biaya karena kerusakan pada peralatan berarti peralatan yang rusak harus diganti dengan yang baru atau diperbaiki dengan biaya yang tidak sedikit.

3. Upaya Penanggulangan

Pada saat proses bongkar muat sering terjadi halangan-halangan yang tidak diinginkan dan dapat menghambat proses bongkar muat. Halangan tersebut bisa terjadi karena kesalahan manusia, kerusakan alat, maupun keadaan cuaca yang kurang baik. Ada beberapa cara maupun langkah yang harus dilakukan untuk mencegah hambatan-hambatan di atas, antara lain :

a. Hambatan karena Manusia

1) Mematuhi Prosedur Proses Pembersihan Ruang Muat (Tank Cleaning) yang Benar

Ada beberapa langkah yang harus dilakukan dalam membersihkan ruang muat supaya bersih dan siap untuk dimuati kembali serta tidak terjadi kontaminasi muatan sehingga dapat menimbulkan kerugian. Adapun langkahlangkah pembersihan ruang muat yaitu :

a) Precleaning (pembersihan awal)

Langkah pencucian pendahuluan ini dilakukan dengan menggunakan media air laut maupun air tawar untuk mengangkat atau mengosongkan sisa-sisa minyak di bellmouth pada 
dasar tangki dan pipa serta pompa muatan. Proses ini harus sesegera mungkin dilaksanakan setelah kegiatan proses bongkar dilaksanakan agar tangki muat cepat bersih dan tidak memerlukan waktu yang tidak terlalu lama $( \pm 15$ menit). Bilamana muatan yang dilakukan pencucian merupakan muatan yang tidak diperbolehkan dibuang ke laut maka hasil pencucian proses ini dibuang ke tangki slop (slop tank)

b) Cleaning (pembersihan) Proses ini dapat dilakukan dengan menggunakan air tawar atau campuran air deterjen, menggunakan air laut serta menggunakan butterworth. Pencucian dengan air laut bertujuan untuk memaksimalkan dalam pembersihan tangki supaya sisa muatan yang dicuci benar-benar telah habis dari tangki. Hal ini bisa menggunakan air dingin maupun air panas ataupun air hangat. Lama waktu pembersihan tergantung dari volume tangki dan juga jenis muatan yang dicuci. Pada pencucian tangki juga perlu diperhatikan bahwa ada beberapa muatan yang jika dicuci menggunakan air laut dingin mengakibatkan timbulnya bercak-bercak putih di dinding atau permukaan tangki. Di antara proses pencucian dengan air laut atau air tawar terkadang diselingi pencucian menggunakan air sabun atau juga dengan menggunakan bahan kimia tertentu. Hal ini dilakukan untuk muatanmuatan yang perlu penanganan khusus akibat dari sifat minyak atau kimiawinya. Beberapa bahan yang sering digunakan di antaranya: teepol, de graser, dll.

c) Rinsing (pencucian)

Langkah ini merupakan sebuah proses pembilasan tangki muat menggunakan air panas atau air dingin setelah tangki muat dicuci dengan air sabun atau deterjen. Pembilasan ini dilakukan dengan waktu yang lebih singkat dari penyemprotan air laut.

d) Flushing (pembilasan)

Langkah ini merupakan suatu langkah yang sangat penting untuk dilakukan yang bertujuan untuk menghilangkan sisa muatan dari tangki dengan menyemprotkan air kedalam tangki menggunakan butterworth.

e) Steaming (penguapan)

Merupakan kegiatan penguapan tangki yang bertujuan untuk menghilangkan bau dari muatan sebelumnya atau kadar garam akibat pencucian air laut. Uap yang digunakan harus cukup panas dan biasanya mencapai suhu $60^{\circ} \mathrm{C}$.

f) Mopping (pengelapan)

Proses ini dilakukan untuk mengangkat sisa cairan yang sudah tidak bisa lagi dihisap oleh pompa, jadi bagian yang belum kering dilap. Perlu diingat sebelum melakukan proses mopping ini yaitu harus mengeluarkan sertifikat Enclosed Space Entry Permit yaitu suatau sertifikat yang dikeluarkan untuk orang yang akan memasuki tangki atau 
compartment yang lama dalam keadaan tertutup. Tangki yang dimasuki adalah tangki yang bersih dan harus aman dari segi kadar oksigen, kadar racun maupun hidrokarbonnya. Untuk itu diperlukan satu tahapan tambahan lagi yaitu Gas Freeing (pembebasan gas).

2) Meningkatkan Keterampilan Para Petugas Bongkar Muat

Keterampilan petugas bongkar muat sangat diperlukan karena itu dapat mempengaruhi cepat atau lambatnya kegiatan bongkar muat. Semakin cerdas dan terampil petugas bongkar muat maka semakin cepat juga proses bongkar muat. Di bawah ini langkah-langkah yang harus dilakukan untuk meningkatkan kinerja petugas bongkar muat, antara lain:

a) Menyelenggarakan

Pendidikan dan Pelatihan

Kegiatan ini bertujuan untuk memberikan pendidikan dan pelatihan sebagai upaya untuk meningkatkan keterampilan dan kompetensi petugas bongkar muat di seluruh pelabuhan Indonesia. Ini sebaiknya merupakan program pemerintah untuk memberi perlindungan dan meningkatkan kemampuan para petugas bongkar muat dalam menghadapi persaingan masyarakat ekonomi ASEAN. Selain itu dengan adanya pelatihan tersebut, meski nantinya ada perusahaan yang masuk dan memperkerjakan pekerja lain, pekerja yang sudah terlatih dapat membantu membimbing pekerja baru dan tetap bisa bersaing dengan baik. b) Mengadakan Familiarisasi

Familiarisasi

merupakan kegiatan sangat penting, karena untuk memperkenalkan alat-alat yang digunakan pada proses bongkar muat dan langkahlangkah yang harus diambil ketika kegiatan bongkar muat untuk para pekerja bongkar muat yang baru atau yang baru bergabung dengan perusahaan. Familiarisasi dapat dilakukan dengan beberapa cara, yaitu orientasi di kapal maupun di pelabuhan, program familiarisasi, handing over, training video dan lain-lain. Oleh karena itu, mengadakan orientasi dan pengenalan baru sesuai dengan situasi yang ada inilah pentingnya familiarisasi dan serah terima antara yang baru dan yang lama harus dijalankan sebenar-benarnya. Jika ada TKBM atau ABK yang baru pertama kali bekerja tentu saja akan menemui banyak kesulitan dalam beradaptasi di lingkungan maupun di kapal, demikian juga untuk mengerti dan melaksanakan tugasnya, untuk itu dalam melaksanakan suatu pekerjaan harus ada orang yang mengawasi, memberi pengarahan, apa yang harus dikerjakan dan menanamkan rasa tanggung jawab atas tugas yang sudah diberikan.

c) Menjadwalkan Pelatihan (Training) secara Berkala

Tujuan diadakan pelatihan berkala adalah untuk membiasakan para petugas bongkar muat dalam penggunaan alat-alat pada kegiatan supaya para petugas lebih terlatih dan tahu 
tindakan apa yang harus dilakukan dalam situasi tertentu. Selain itu dengan diadakannya pelatihan secara berkala akan berdampak positif terhadap hasil kerja yang dilakukan, yaitu kerja lebih cepat dan efisien sehingga menghasilkan hasil yang maksimal dan memuaskan.

d) Memberikan reward dan punishment

Reward merupakan suatu bentuk penghargaan yang diberikan kepada pegawai atau karyawan yang melaksanakan tugas dengan baik, sedangkan punishment merupakan sebuah bentuk hukuman atau sanksi yang diberikan kepada karyawan atau pegawai yang melanggar aturan yang telah ditetapkan.

PT. Pelindo III cabang Tanjung Emas Semarang juga menerapkan pemberian penghargaan dan sanksi kepada karyawan atau pegawai yang dilaksanakan setiap bulan. Penghargaan yang diberikan kepada karyawan atau pegawai yang bekerja dengan baik disebut dengan penghargaan "pegawai teladan" dan pihak perseroan akan memberikan bonus berupa barang yang bermanfaat. Sedangkan sanksi yang diberikan kepada pegawai atau karyawan yang melanggar aturan yang berat yaitu diturunkan dari jabatannya.

b. Hambatan karena Kerusakan pada Peralatan

Pada proses bongkar muat, peralatan sangat berpengaruh karena dengan peralatan bongkar muat menjadi lebih cepat, mudah, dan efisien. Namun, jika peralatan rusak, proses bongkar muat menjadi terhambat. Maka dari itu untuk menanggulangi kerusakan pada peralatan harus menjalankan perawatan terhadap peralatan bongkar muat.

Perawatan terhadap peralatan bongkar muat khususnya pipa muat, sangat menentukan dalam proses pengoperasian saat bongkar ataupun muat. Kegagalan dari kegiatan bongkar muat salah satunya ditentukan oleh kelayakan pada peralatan bongkar muat.

Sebelum dilaksanakanya bongkar muat dilakukan pengecekan seluruh peralatan yang digunakan, termasuk pipa-pipa. Dengan kata lain, jika standar prosedur manual yang telah ditetapkan oleh perusahaan dan pihak kapal diterapkan dengan benar, maka tidak akan terjadi keterlambatan dalam hal membongkar maupun memuat yang dapat terjadi karena adanya kebocoran, karena perawatan pipa yang kurang.

Dalam ISM Code dijelaskan pentingnya perawatan kapal dan peralatannya. Oleh sebab itu, kapal dan peralatannya harus dirawat dan dijaga sebaik mungkin. Perusahaan juga diharapkan menyusun prosedur untuk menjamin bahwa peralatan di kapal maupun di pelabuhan dirawat sesuai dengan persyaratan dari peraturan klasifikasi yang terkait dan persyaratan tambahan yang ditetapkan oleh perusahaan. Dalam memenuhi persyaratan tersebut di atas, perusahaan harus menjamin bahwa :

1) Pemeriksaan dilaksanakan dalam kurun waktu yang tepat.

2) Setiap ketidak sesuaian dilaporkan dengan penyebabnya.

3) Pencatatan tentang kegiatankegiatan tersebut di atas terpelihara.

Perseroan juga dapat menerapkan sistem perawatan berencana dengan menggunakan aplikasi yang banyak berkembang di era revolusi industri 
4.0 ini sehingga menunjang kepuasan pelanggan karena mendapat pelayanan yang baik (Relani \& Hidayat, 2019).

c. Hambatan karena Cuaca Buruk

Pada saat proses bongkar muat keadaan cuaca sangat berpengaruh, terutama pada saat proses pembersihan ruang muat sebelum memuat, karena pada saat pembersihan ruang muat (tank cleaning), cuaca harus cerah dan mendukung agar proses pembersihan ruang muat berjalan lancar. Apabila cuaca buruk atau hujan dapat menghambat pembersihan tangki muat.

Maka dari itu, langkah yang harus diambil adalah kita harus bisa memprediksi ataupun memperkirakan kapan cuaca buruk terjadi dan cuaca mendukung terjadi. Selain itu, kita harus bisa mengambil langkah yang tepat dan cepat. Kita harus berpikir kreatif serta mempunyai rencana untuk mencegah apabila cuaca buruk terjadi karena faktor alam tidak bisa ditentukan akan keadaanya.

\section{SIMPULAN}

Dari pembahasan di atas, penulis dapat menyimpulkan bahwa untuk meningkatkan proses bongkar muat minyak produk di dermaga curah cair PT. Pelindo III cabang Tanjung Emas Semarang adalah sebagai berikut :

1. Adanya hambatan yang disebabkan kesalahan manusia yaitu karena kurang optimalnya persiapan ruang muat dan pencucian tangki (tank cleaning) bisa mengakibatkan kontaminasi muatan karena beda jenis muatan akibat dari kurang bersihnya saat pencucian tangki muat. Selain itu hambatan juga disebabkan kurang terampilnya TKBM yang dapat menghambat kegiatan bongkar muat akibat dari kurangnya pengetahuan mengenai langkah yang harus dilakukan pada saat bongkar muat dan prosedur yang harus dilaksanakan pada saat kegiatan. Solusinya adalah mengikuti langkah-langkah yang harus dilakukan saat pembersihan tangki muat dan meningkatkan keterampilan para petugas bongkar muat dengan cara memberi pendidikan dan pelatihan, mengadakan familiarisasi, menjadwalkan pelatihan secara berkala, serta pemberian reward and punishment.

2. Adanya hambatan yang disebabkan karena kerusakan pada alat yang digunakan untuk bongkar muat. Salah satunya, kerusakan pada pipa yang mengalami kebocoran akibat kurangnya pengecekan sebelum digunakan. Solusinya adalah melakukan perawatan terhadap peralatan yang digunakan dalam proses bongkar muat sesuai dengan aturan dalam ISM Code. Terhadap peralatan yang sudah tidak layak pakai sebaiknya diperbarui atau dilakukan perbaikan.

3. Adanya hambatan yang disebabkan karena cuaca buruk. Pada masalah ini kita sebagai makhluk hidup tidak bisa memastikan kapan cuaca buruk terjadi, karena cuaca buruk dapat mengganggu pada saat proses pembersihan ruang muat (tank cleaning). Solusinya adalah kita harus bisa memprediksi ataupun memperkirakan kapan cuaca buruk dan cuaca mendukung terjadi. Kita harus bisa mengambil langkah yang tepat dan cepat, berpikir kreatif, serta mempunyai rencana untuk mencegah apabila cuaca buruk terjadi karena faktor alam tidak bisa ditentukan keadaannya. Kita bisa berkoordinasi dengan Badan Meteorologi, Klimatologi, dan Geofisika (BMKG) untuk memantau prakiraan cuaca.

\section{DAFTAR PUSTAKA}

Adi, D. B. S., \& Djaja, I. K. (2008). Nautika Kapal Penangkap Ikan. Journal of Chemical Information and Modeling (Vol. 53, Issue 9). 
Jakarta: Direktorat Pembinaan SMK Depdiknas.

Akhbar, M. R., \& Darmana, E. (2019). Study Penanganan Kerusakan Komponen yang Terjadi pada RTG di Terminal Peti Kemas Koja Jakarta. Jurnal Sains Dan Teknologi Maritim, 19(2), 142-150.

Alabatjo. (2012). Optimalisasi Persiapan Ruang Muat Untuk Muatan Produk Minyak di Kapal MT. Princess Adaeze. Jakarta: Sekolah Tinggi Ilmu Pelayaran.

Antika, E., Rochanda, Lesmana, E. J., \& Marcelina, S. (2019). Upaya Mencegah Terjadinya Kontaminasi Terhadap Penanganan Muatan. Jurnal Sains Teknologi Transportasi Maritim, I(2), 13-19.

Badudu, J. S., \& Zain, S. M. (2001). Kamus Besar Bahasa Indonesia. Jakarta: Pustaka Sinar Harapan.

Cahyanto, R. D. (2019). Penanganan Bongkar Muat Muatan Minyak di Kapal. Semarang: Politeknik Bumi Akpelni.

Gianto, H., \& Martopo, A. (2004). Pengoperasian Pelabuhan Laut. Politeknik Ilmu Pelayaran.

Kementerian Perhubungan Republik Indonesia. (2011). Keputusan Menteri Perhubungan Nomor: KP 88 Tahun 2011 tentang Pemberian Izin Usaha kepada PT. Pelabuhan Indonesia III (Persero) sebagai Badan Usaha Pelabuhan.

Martopo, A. (2001). Penanganan Muatan. Semarang: Badan Penerbit
Buku Maritim.

Moenir, H. A. . (2006). Manajemen Pelayanan Umum di Indonesia. Jakarta: Bumi Aksara.

Relani, I., \& Hidayat, E. N. (2019). Pengaruh Revolusi Industri 4.0 terhadap Online Service Terminal Petikemas Koja Jakarta. Majalah Ilmiah Gema Maritim, 21(2), 120128.

Safrianda, M., Rinaldi, \& Fatnanta, F. (2016). Analisis Penyebab Keterlambatan Bongkar Muat Barang Akibat Faktor Peralatan (Studi Kasus : Dermaga Pelabuhan Dumai). Jom FTEKNIK, 3(2), 1-12.

Huda, Samsul; Andri Yulianto, \& Taufik Qur Romadhon. (2017). Pengoperasian Cargo Control Room untuk Kelancaran Proses Bongkar Muat pada Kapal MT. Ketaling. Dinamika Bahari, 8(1), 1855-1866.

Sudjatmiko, F. D. C. (2015). PokokPokok Pelayaran Niaga. Jakarta: Akademika Pressindo.

Suyono, R. P. (2007). Shipping: Pengangkutan Intermodal Ekspor Impor Melalui Laut. Jakarta: PPM.

Undang-Undang Republik Indonesia No. 17 Tahun 2008 Tentang Pelayaran. (2008).

Widodo, B. L. H., \& Wahyuni, E. T. (2020).

Manajemen Penanggulangan Tumpahan Minyak di Laut Akibat dari Pengoperasian Kapal. Majalah Ilmiah Gema Maritim, 22 (1), 60-66. 